\title{
First record of scab disease of almond caused by Cladosporium carpophillum in India
}

\author{
NASSREEN F. KACHO ${ }^{1 *}$, KHURSHEED AHMED ${ }^{1}$, MOHAMMED HUSSAIN², SABA BANDAY ${ }^{1}$, MUSHTAQ A. BHAT ${ }^{1}$ \\ and NISAR A. QAZI ${ }^{1}$ \\ ${ }^{1}$ Division of Plant Pathology, Sher-e-Kashmir University of Agricultural Sciences and Technology of Kashmir, Shalimar Campus, \\ Srinagar 191 121, Jammu \& Kashmir, India \\ ${ }^{2}$ Department of Zoology, Government Degree College, Kargil 194 103, Jammu \& Kashmir, India
}

Received: 5 April 2017/ Accepted: 6 June 2017/ Published online: 24 July 2017

(c) Indian Phytopathological Society 2017

\begin{abstract}
In India Almond (Prunus amygdulus Batsch.) is commercially grown in Jammu and Kashmir state. During 2012 -2014, circular to oval lesions with brown centers and slightly raised purple margins were observed on twigs of almond, while on leaves lesions appeared as many small, indistinct, somewhat circular, greenish yellow blotches under surface. On fruit, spots were dark grey to black sooty appearance that coalesced into large dark blotches. Average disease intensity of 24.30 per cent and 26.50 per cent was recorded on leaves and twigs respectively. The culture obtained from the diseased sample was identified as Cladosporium carpophillum Thum. on the basis of the colony and morphological characters. This is the first report of scab of Almond fruit caused by $C$. carpophillum in India. This disease can seriously affect Almond quality and yield, so effective measures should be implemented to control it.
\end{abstract}

Keywords: Almond, Scab, Cladosporium carpophillum

Almond (Prunus amygdulus Batsch.) is one of the most important nut crops with wide spread popularity, is cultivated in temperate regions of the world. In India almond is mainly grown in Jammu and Kashmir and Himachal Pradesh. However, commercial cultivation of this nut is mainly confined to the state of Jammu and Kashmir occupying an area of 17,153 ha with an annual production of 12497 metric tonnes (Anonymous, 2013; Khosla et al., 2009).

Almond orchards surveyed in different districts of Kashmir valley during 2012-2014 were found to be affected by scab disease. Average disease intensity of 24.30 per cent and 26.50 per cent was recorded on leaves and twigs respectively. The disease mainly appeared first on twigs in the first week of May and later on leaves in the second week of May and in severe cases on fruits. On twigs, lesions were circular to oval with brown centres and slightly raised purple margins, while on leaves lesions appeared as many small, indistinct, somewhat circular, greenish yellow blotches under surface. The lesions later enlarge same reaching $10 \mathrm{~mm}$ or more in diameter. With the production of spores, they take an olivaceous appearance and eventually brownish black. On fruit, spots were dark grey to black sooty appearance and coalesced into large dark blotches (Fig. 1). The mycelial colony on PDA was dark green turning black after 30-35 days of incubation in pure culture. Conidiophores were solitary, erect, somewhat flexuous slightly constricted at septa and pale brown in colour.
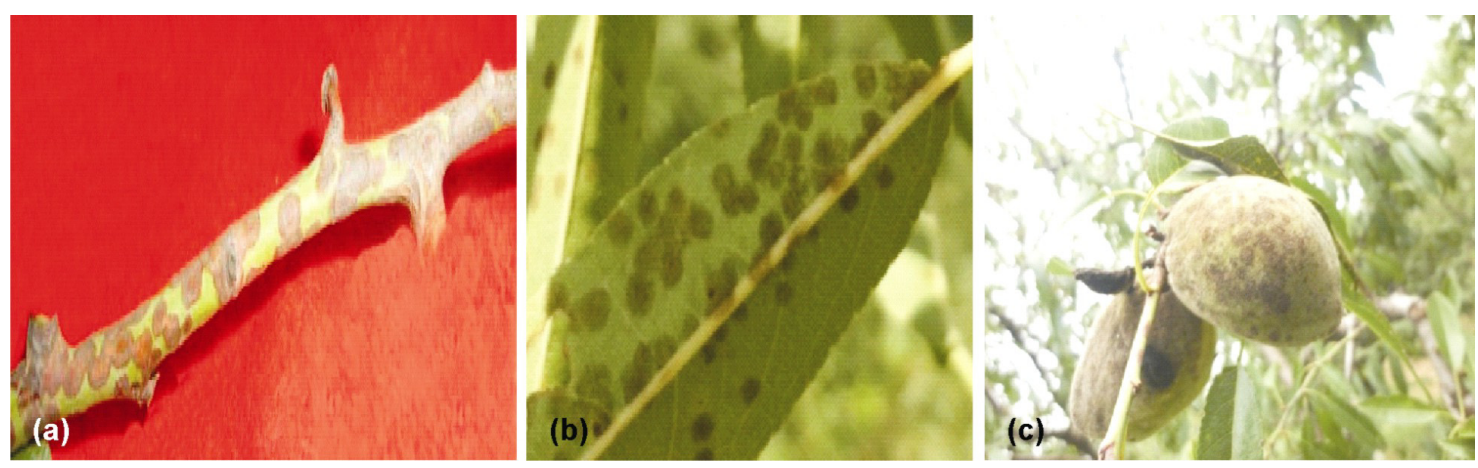

Fig. 1. Natural scab symptoms on the (a) Twigs (b) Leaves and (c) Fruits of Almond

\footnotetext{
${ }^{\star}$ Corresponding author: ftmkacho898@gmail.com
} 
Conidia were mostly solitary rarely catenate, oval to cylindrical and straight in shape, hyaline, 0 to 1-septate, measuring 11.6-20.88 × 4.64-6.96 $\mathrm{mm}$ in size.

On the basis of morphological and colony characters, the fungus was identified as Cladosporium carpophillum Thum. Final confirmation was obtained from Indian Type Culture Collection (ITCC), IARI, New Delhi, under I.D. No. 9276.13 and Ref. No. 28101.

Scab caused by dematiaceous hyphomycete, as Cladosporium carpophillum on peaches in India was first reported by Khosla (2009). But a critical survey of literature revealed that the pathogen has not been reported on almond in India (Jamaluddin et al., 2009). Therefore, this account is the first record of C. carpophillum causing scab disease in almond from India.

\section{ACKNOWLEDGEMENTS}

Authors are thankful to Professor M.A. Beigh, Ex. Professor, Division of Plant Pathology, Sher-e-Kashmir University of Agricultural Sciences and Technology of Kashmir, Shalimar Campus, for his help in the study of the disease.

\section{REFERENCE}

Anonymous (2013). Directorate of Horticulture, Government of Jammu and Kashmir: pp. 226.

Chinky S (2015). District wise production of fresh and dry fruits in Jammu and Kashmir. Int. J. Economic Business Rev. 3: 128-132.

Jamaluddin S, Goswami MG and Ojha BM (2009). Fungi of India 1989-2001. Scientific Publ. (India), Jhodpur, pp. 326.

Khosla K, Bhardwaj SS and Gupta AK (2009). Scab disease of peach and nectarine. J. Mycol. Plant Pathol. 39: 342-342. 